REPORTS OF MORPHOLOGY
Official Journal of the Scientific Society of Anatomists,
Histologists, Embryologists and Topographic Anatomists
of Ukraine

\title{
Structural organization of the ileum of laboratory animals in normal and in a comparative view aspect
}

Sydorenko M.I.

Ukrainian Medical Dental Academy, Department of Clinical Anatomy and Operativ Surgery, Poltava, Ukraine

\section{ARTICLE INFO}

Received: 26 February, 2019

Accepted: 26 March, 2019

UDC: $611.344-092.9$

\section{CORRESPONDING AUTHOR}

e-mail: sidorenko999@ukr.net Sydorenko M.I.
In recent decades, diseases of the digestive system that require immediate, both therapeutic and surgical treatment, have become widespread, and it is therefore a natural task to find new and optimize existing technologies and methods for correcting the above-mentioned nosologies. Preclinical studies of such developments are conducted exclusively on laboratory animals and knowledge of the morphological features of their structure for further comparison with the morphology of similar human organs is an urgent task of modern medical and biological science. The purpose of the study was to study the structural organization of the ileum of rabbits in comparative species and to obtain control data on its morphological features. Adequate research methods were used in the work according to the set goal, namely: histological, histochemical, electron microscopic, morphometric and statistical and biopsies of the ileum of 10 rabbits were studied. The correctness of the distribution of traits by each of the variations obtained, the average values for each trait studied, standard errors and standard deviations were evaluated. The significance of the difference of values between independent micrometric values in the normal distribution of features was determined by Student's criterion. The paper describes the main structural components of the ileum of rabbits and compared with similar structures of the human ileum. The ileum of rabbits, as in humans, has been determined to have four membranes: mucous, submucosal, muscular and serous. The mucous membrane is constructed from the epithelial layer, which is located on the basement membrane and the muscular plate and contains cellular elements (exocrinocytes, enterocytes of various kinds, elements of the diffuse endocrine system associated with the mucous membrane, intraepithelial lymphocytes), blood and lymphatic vessels and nerve endings. The submucosa is composed of loose fibrous connective tissue, which contains collagen and reticular fibers, elements of diffuse lymphoid tissue, blood vessels, and nerve endings. The muscular and serous membranes are constructed in the same way as in the human ileum. Thus, after the study, it was determined that the morphological organization of the ileum of rabbits at the optical and electron microscopic levels has general patterns of structure similar to those in the ileum of the human.

Keywords: ileum, exocrinocytes, endocrinocytes, lymphocytes, arterioles, capillaries, venules.

\section{Introduction}

Digestive diseases are one of the most widespread not only in the territory of our country, but in the whole world. Mortality from digestive diseases is a significant proportion of all diseases [12, 13, 15]. In recent years, there has been a steady increase in the incidence of malignant tumors of the small intestine, including malignant non-epithelial tumors, most often stromal tumors accounting for 4-10\% $[9,14]$. Despite the fact that the therapeutic options for conservative therapy of small bowel disease have expanded significantly over the last decade, about $20-60 \%$ of patients with inflammatory bowel disease may need surgical treatment over the course of their lives [2, 17, 18].

In the available literature, data are available on the morphological features of the structure of both the middle section of the digestive tube as a whole and its individual parts $[3,4,5,6,7,8]$. However, these studies relate to the morphology of the rat digestive tube, and the structural features of the rabbit ileum have not been studied. The 
urgency of studying this issue is due to the fact that rabbits are used as laboratory animals in the development of tactics for surgical treatment of diseases of the small intestine, which is related to the linear dimensions of the latter. Based on the above study of morphology of the ileum of rabbits is a normal medical and biological task, and the data obtained will serve as reference indicators in the course of a series of experimental developments.

The purpose of the study was to study the structural organization of the ileum of rabbits in comparative species and to obtain control data on its morphological features.

\section{Materials and methods}

This study used rabbits of the "Chinchilla" breed $(n=10)$. Animals were kept and all manipulations were carried out in accordance with the "Rules for the Use of Laboratory Experimental Animals" (2006, Annex 4) and the Declaration of Helsinki on Animal Welfare, Law of Ukraine "On the Protection of Animals against Cruelty" (No. 3447-IV of 21.02. 2006) in compliance with the requirements of the Bioethics Commission of the Ukrainian Medical Dental Academy, in accordance with the provisions of the "European Convention for the Protection of Vertebrate Animals Used for Experimental and Other Scientific Purposes" (Strasbourg, 1986).

Histological, ultramicroscopic, morphometric and statistical methods of investigation were used in the work. For this purpose, in the operating department of clinical anatomy and surgery, surgery was performed on the small intestine in the ileum. To determine the main morphological parameters of the ileum biopsy was removed and compacted into paraffin and epoxy resin according to conventional methods. From paraffin blocks, semi-thin sections of 4-5 $\mu \mathrm{m}$ thick were made, which were then stained with hematoxylin and eosin, followed by Van Gizon with Harte refinement. Thin sections 1-2 $\mu \mathrm{m}$ thick were made of epoxy blocks and stained with methylene blue and toluidine blue. Further histological sections were examined using an Olympus C 3040-ADU digital microscope with programs adapted for this study (Olympus DP - Soft, license no. VJ285302, VT310403, 1AV4U13B26802) and Biorex 3 (serial number 5604). Morphometric studies were performed using a system of visual analysis of histological preparations. Images of histological specimens on a computer monitor were taken from a microscope and using a Visiion CCD Camera. Morphometric studies were performed using VideoTest5.0, KAAPA Image Ваsета Microsoft Excel software on a personal computer. Ultramicroscopic investigations were performed on the basis of the electron microscopy laboratory of the Ternopil National Medical University named after I. Gorbachevsky in accordance with the concluded agreement on scientific cooperation.

The average size of the intestinal wall was determined morphometrically, namely: the average total thickness of the intestinal wall; the average thickness of the mucous membrane; the average thickness of the submucosa; the average thickness of the muscle; the average thickness of the serous membrane. The morphometric characteristics of the elements of the hemomicrocirculatory bed were determined in accordance with the guidelines [11, 12, 18] and the index of their capacity (Wogenworth index) was determined. We measured the average height of the villi, the average apical width of the villi, the average basal width of the villi, the average diameter of the lumen of the lymphatic vessel of the villi, the average depth of the crypts, the average diameter of the crypts. In parallel, the average number of structural elements of the ileum of the ileum in the villi was calculated: the average number of columnar epitheliocytes with a border; the average number of goblet cells; average number of endocrinocytes; average number of intraepithelial lymphocytes; in crypts: average number of columnar epitheliocytes; the average number of goblet cells; average Paneth cell count; average number of endocrinocytes.

The statistical methods of the study evaluated the correctness of the distribution of traits by each of the variations obtained, the average values for each trait studied, standard errors and standard deviations. The significance of the difference between independent micrometric values in the normal distribution of features was determined by the Student's test.

\section{Results}

The study found that the ileum of rabbits is a tubular organ which is made of mucous, submucosal, muscular and serous membranes. The total wall thickness averaged $401.3 \pm 12.4 \mu \mathrm{m}$.

The average thickness of the mucous membrane was $288.6 \pm 8.3 \mu \mathrm{m}$. The mean thickness of the submucosa was $17.12 \pm 2.25 \mu \mathrm{m}$. The average thickness of the muscle was determined in the range $97.47 \pm 1.35 \mu \mathrm{m}$, and the mean thickness of the serous membrane was $8.161 \pm 1.871 \mu \mathrm{m}$. As part of the mucous membrane of the ileum was determined epithelial plate, which was represented by a single-layer columnar epithelium. Below it was a lining of the mucous membrane, which in turn consisted of loose fibrous connective tissue, and even more deeply visualized a muscular lining of the mucous membrane, which was built of several layers of smooth myocytes (Fig. 1).

On histological preparations the mucous membrane of the ileum of the rabbits formed a kind of relief pattern in the form of villi and crypts. The villi of the ileum of the ileum had a finger-like shape, and their average height was $179.2 \pm 3.6 \mu \mathrm{m}$. The average thickness of the villi varied depending on its topography. Thus, the mean apical width of the villi was $33.97 \pm 0.54 \mu \mathrm{m}$ and the mean basal width was $39.22 \pm 0.55 \mu \mathrm{m}$. In the middle of the villus was a lymphatic duct that was closely linked to the muscular plate of the ileum of the ileum. Its average lumen diameter was $12.16 \pm 1.81 \mu \mathrm{m}$. Reticular fibers and a large number of hemomicrocirculatory bed elements were visualized 


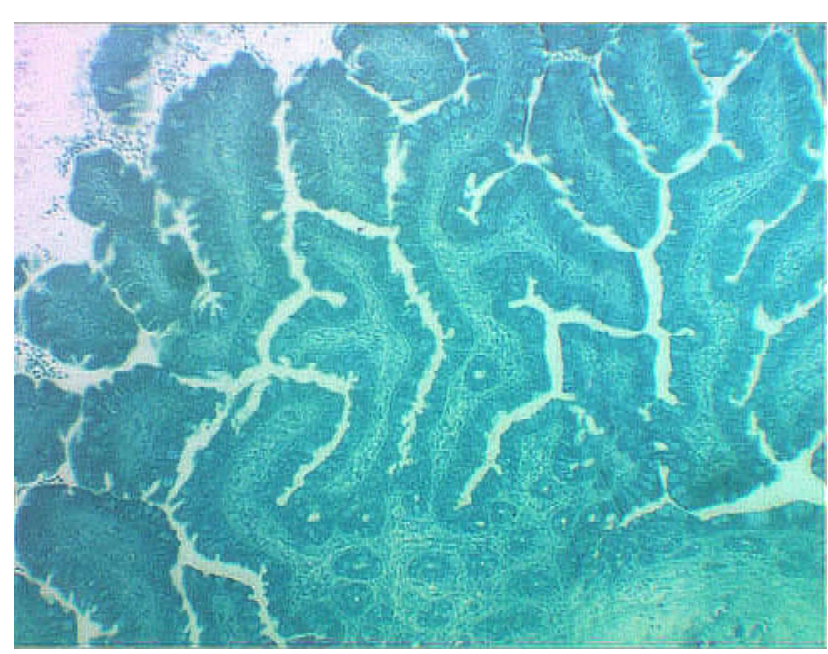

Fig. 1. General plan for the structure of the mucous membrane of the ileum. Thin section. Methylene blue. x100.

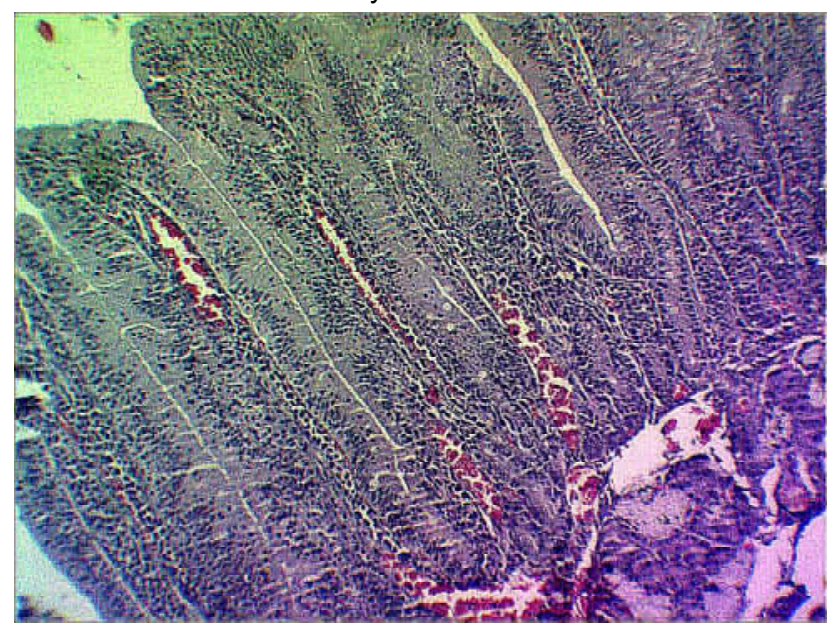

Fig. 2. Microenvironment of the villi of the ileum. Semi-thin section. Hematoxylin and eosin. $x 400$.

around it, but capillaries prevailed among the latter (Fig. 2).

The cellular composition of the ileum of the ileum was represented by different types of epitheliocytes. On histological preparations their varieties were clearly visualized: enterocytes with banded edges, goblet exocrinocytes, microfold cells. At the same time, prismatic cells with oxyphilic cytoplasm and a well-developed nuclear apparatus were visualized among the above-mentioned epitheliocytes. In our opinion, these are stem cells, which in humans are localized only in the crypts and in a small number in the basal departments of the villi, and in rabbits they are also available in the lateral departments.

Cells with a striped border were located mainly in the apical departments of the villi and had a cylindrical shape, an oval nucleus. A well-developed granular endoplasmic reticulum and lysosome complexes were visualized in their cytoplasm. The average number of columnar enterocytes with a border in the composition of the ileum of rabbits was $92.35 \pm 1.84$ in 10 fields of view. The goblet exocrinocytes were located predominantly in the middle departments of the villi. Their mean number was $10.98 \pm 2.14$ in 10 fields of view. They had an elongated shape that, in our opinion, depended on the secretory cycle phase of these exocrinocytes. At the ultramicroscopic level, they had a variable shape: with the accumulation of secretions, the apical part expanded and the basal part narrowed and contained a nucleus and an endoplasmic reticulum. Above the nucleus, a well-developed Golgi complex was visualized (Fig. 3).

At the same time, elements of the diffuse endocrine system were visualized among the cellular composition of the epithelial layer of the ileum of the ileum. At the optical level, endocrinocytes had a triangular or polygonal shape with a sharply basophilic cytoplasm and, as a rule, capillaries were visualized next to them. The average number of endocrinocytes was $0.741 \pm 0.081$ in 10 fields of view. At the ultramicroscopic level, endocrinocytes had a rounded nucleus with a large amount of heterochromatin. The moderately developed granular endoplasmic reticulum and the Golgi complex were determined in the nucleolar zone. In the cytoplasm of these cells, a large number of secretory granules with signs of polymorphism were determined. It was noted that the cells of the diffuse endocrine system had no direct contact with the lumps of the villi and were separated from them by a group of little differentiated cells. Also, intraepithelial lymphocytes with classical structure were visualized among the cellular composition of the epithelial layer of the ileum of the ileum, and their average number was $0.382 \pm 0.041$ in 10 fields of view.

Also among the cellular composition of the epithelial layer of the mucous membrane of the villi in its basal divisions were found micro-folding cells, which on their apical surface formed the invagination of the nuclear membrane. Histotopographically, these cells were usually located near the clusters of lymphoid tissue. When visualizing the electronograms, it is noteworthy that under the microfolding cells there is no basement membrane, that is, the

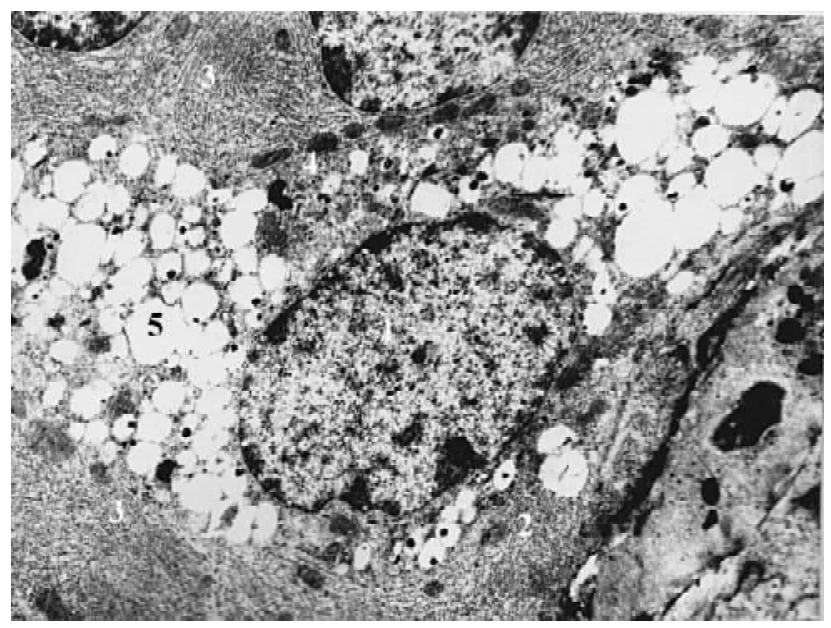

Fig. 3. Ultrastructure of goblet exocrinocytes in the composition of rabbit ileum villi. Electronogram. x10000. 
impression that the above cells perforate the latter and due to such interaction is a close connection through the microfolding cells of the lymph nodes of the lining of the lamina.

Histological preparations between adjacent villi in the depth of the mucous membrane closer to the submucosal layer were determined by the ingrowth into the own plate of the epithelial layer in the form of tubes. By analogy with such structures in the human mucosa, we identified them as crypts whose average diameter was $20.48 \pm 1.63 \mu \mathrm{m}$. These structures were located with respect to the epithelial layer at different and different depths, and their mean depth was $78.66 \pm 16.11 \mu \mathrm{m}$. The average number of crypts was $7.641 \pm 0.162$ in 10 fields of view.

Among the cellular elements of the crypts were determined: columnar enterocytes with a border whose average number was $22.67 \pm 2.18$ in 10 fields of view; unbranched columnar enterocytes whose mean number was $30.17 \pm 3.62$ in 10 fields of view; goblet-shaped exocrinocytes whose mean number was determined at $31.02 \pm 3.62$ in 10 fields of view; Paneth cells had an average number $11.67 \pm 1.84$ in 10 fields of view; endocrinocytes of the diffuse endocrine system associated with the mucosa, the average number of which was determined at $7.821 \pm 2.362$ in 10 fields of view; intraepithelial lymphocytes the average number of which was $1.242 \pm 0.061$ in 10 fields of view.

Among the elements of the hemomicrocirculatory bed were identified arterioles, capillaries and venules. They were located in both the mucous and submucosal membranes. At the optical level, the arterioles were visualized as structures that clearly contained three membranes and were formed by a layer of endothelial cells located on an elastic membrane; layer of smooth myocytes; and externally they were covered with a non-continuous layer of adventitial fibroblasts. In the mucosa, the mean outer diameter of the arterioles was $11.08 \pm 0.84 \mu \mathrm{m}$; their average lumen diameter was determined at $7.222 \pm 0.911 \mu \mathrm{m}$; the mean wall thickness was $3.863 \pm 0.091 \mu \mathrm{m}$. The capacity (Wogenworth index) of the arterioles of the mucous membrane of the ileum of rabbits was $135.5 \pm 4.4$. The submucosal arterioles had an average outer diameter at $10.43 \pm 0.81 \mu \mathrm{m}$. Their average lumen diameter was determined at $9.732 \pm 0.412 \mu \mathrm{m}$, the mean wall thickness was $0.712 \pm 0.061 \mu \mathrm{m}$, and the Wogenworth index was $14.91 \pm 0.86$.

Capillaries on histological specimens were defined as vessels of small caliber whose wall was formed by a layer of endothelium located on the basement membrane and a discontinuous layer of serocytes, and unlike the arterioles, the elastic membrane was absent. In the mucosa, the capillaries had an average total diameter $6.153 \pm 0.092 \mathrm{~mm}$. Their average lumen diameter was $5.283 \pm 0.084 \mathrm{~mm}$, the mean wall thickness was $0.872 \pm 0.093 \mathrm{~mm}$, and the Wogenworth index was $35.69 \pm 1.18$. In the submucosal layer, the average outer diameter of the capillaries was $6.913 \pm 0.042 \mathrm{~mm}$, the average lumen diameter was $6.132 \pm 0.022 \mathrm{~mm}$, the average wall thickness was determined at $0.781 \pm 0.023 \mathrm{~mm}$, and the Wogenworth index was determined at $27.09 \pm 1.02$.

Venules on histological specimens were defined as irregularly shaped structures and endothelial cells on the basement membrane were visualized as part of their walls, which were covered externally by a continuous layer of fibroblasts. In the mucosa, the outer diameter of the venules was $12.06 \pm 0.81 \mathrm{~mm}$, the average lumen diameter was determined at $8.192 \pm 0.873 \mathrm{~mm}$, the average wall thickness was $3.873 \pm 0.841 \mathrm{~mm}$, and the Wogenworth index was $116.8 \pm 3.24$. In the submucosal layer, the mean outer diameter of the venules was $12.96 \pm 0.77 \mathrm{~mm}$, the average lumen diameter was $10.19 \pm 0.85 \mathrm{~mm}$, and the mean wall thickness was $2.772 \pm 0.032 \mathrm{~mm}$, and the Wogenworth index was determined at $61.74 \pm 1.91$.

\section{Discussion}

Summarizing and analyzing the results obtained, it should be noted that the overall organization of the intestinal wall corresponds to the basic laws of the structure of the ileum of the person, which is confirmed by the data [1]. However, due to the type of nutrition, body placement in space, body weight and linear size of rabbits, they have non-human morphometric measures of medium size, both the wall itself and its layers.

Structural and functional unit of the ileum in humans and rabbits should be considered the crypt villus system. Among the cellular composition of villi in rabbits, as in humans, were columnar cells with a border, goblet exocrinocytes, cells of the diffuse endocrine system associated with the mucosa and intraepithelial lymphocytes. In contrast to the cellular composition of the human ileum, according to data [10], microfold cells that were located in their basal compartments were found in the composition of the villi of the rabbits ileum.

Among the cellular elements of the villi of the mucous membrane of the ileum of the rabbits were columnar enterocytes with a border of their percentage of the total number of cellular elements of the villi was $88.34 \%$, which is related to their main function. Goblet-like exocrinocytes accounted for $10.51 \%$, endocrinocytes - $0.71 \%$, intraepithelial lymphocytes - $0.36 \%$ and poorly differentiated epitheliocytes in the villus composition accounted for $0.11 \%$ of the total cell pool. Thus, the system of the cellular pool of the villi of the ileum of the ileum in rabbits provides the processes of absorption of substances, the production and excretion of mucous secretions in the cavity of the villi, and also participates in endocrine regulation and maintenance of immune surveillance. The poorly differentiated cells that are found in the basal departments of the villi belong, in our opinion, to the cambial elements.

Among the cellular elements of crypts, as well as in the crypts of the ileum of the human are defined structural components, namely: columnar enterocytes with a border, columnar enterocytes without a border, goblet 
exocrinocytes, Paneth cells, endocrinocytes, intraepithelial cells. Analyzing the distribution of cellular elements in crypts as a percentage, another tendency for the cryptocurrency to function as part of a morpho-functional unit is determined. Thus, among the whole cell pool crypts, columnar enterocytes with a border were $21.49 \%$, columnar enterocytes without a border were $28.85 \%$, goblet-like exocrinocytes - $29.66 \%$, Paneth cells - $11.16 \%$, endocrinocytes diffuse endocrine system - $7.48 \%$, intraepithelial lymphocytes $-1.24 \%$, low-differentiated cells $-0.17 \%$. Thus, remodeling of the structural components of crypts relative to similar components of the villi indicates a redistribution of functional load toward mucous secretion and secretion, local enhancement of secretion of digestive enzymes and enhancement of local immune protection.

The original data obtained from the study are promising in the future work. They will serve as controls for further experimental development in surgery on the ileum to select the optimal suture material for stitching its wound defect.

\section{References}

[1] Antonyuk, O. P. (2016). Features of organogenesis digestive system of the human. Bulletin of problems in biology and medicine, 4(133), 279-284.

[2] Bilash, S. M. (2013). [Influence of Cryopreserved Placenta on the Morphofunctional State of Stomach Pyloric Glands' Exocrinocytes at Acute Inflammation Processes. Bulletin of problems in biology and medicine, 2(99), 224-227.

[3] Cardamone, C., Parente, R., De Feo, G., \& Triggiani, M. (2016). Mast cells as effector cells of innate immunity and regulators of adaptive immunity. Immunology letters, 178, 10-14. doi: 10.1016/j.imlet.2016.07.003

[4] Gomes, J. R., Ayub, L. C., dos Reis, C. A., Machado, M. J., da Silva, J., Omar, N. F., \& de Miranda Soares, M. A. (2017). Goblet cells and intestinal alkaline phosphatase expression (IAP) during the development of the rat small intestine. Acta histochemica, 119(1), 71-77. doi: 10.1016/j.acthis.2016.11.010

[5] Hryn, V. H., Kostylenko, Y. P., Yushchenko, Y. P., Ryabushko, M. M., \& Lavrenko, D. O. (2018). Comparative histological structure of the gastrointestinal mucosa in human and white rat: a bibliographic analysis. Wiadomosci lekarskie (Warsaw, Poland: 1960), 7(71), 1398-1403. PMID: 30448817

[6] Hryn, V. H., Kostylenko, Y. P., Yushchenko, Y. P., Lavrenko, A. V., \& Ryabushko, O. B. (2018). General comparative anatomy of human and white rat digestive systems: a bibliographic analysis. Wiadomosci lekarskie (Warsaw, Poland: 1960), 71(8), 1599-1602. PMID: 30684346

[7] Hryn, V. H., Kostylenko, Y. P., \& Yachmin' A. I. (2019). Features of white rats stomach anatomical structure. World of medicine and biology, 1(67), 133-137. doi: 10.26724/2079-8334-20191-67-133

[8] Hryn, V. H., Kostylenko, Y. P., Bilash, V. P., \& Tarasenko, Y. A. (2019). Features of angioarchitecture of the albino rats stomach and small intestine. Wiadomosci lekarskie (Warsaw, Poland: 1960), 3(72), 311-317. PMID: 31050973

[9] Hryn, V. H., Kostylenko, Y. P., Bilash, V. P., \& Ryabushko, O. B. (2019). Microscopic structure of albino rats' small intestine.

\section{Conclusions}

1. The ileum of rabbits conforms to the general principles of organization of the intestinal tube of a person, which provides an opportunity for experimental development and implementation of the results.

2. Structural-functional unit of the ileum of rabbits should be considered the villus-crypt system. There is no significant difference between the cellular content of the villus and the crypt in comparison with the similar structure of the villuscrypt system in humans.

3. The peculiarities of the structure of the mucous membrane of the ileum of rabbits in comparison with similar structures in humans is the difference in the cytotographic principle of the location of cellular components.

4. The basic organization of the hemomicrocirculatory bed in the mucous and submucous membranes does not differ from the similar system of the ileum of the person.

5. New, original data obtained may further serve as benchmarks for various types of experimental studies.

Wiadomosci lekarskie (Warsaw, Poland: 1960), 5(72), 733738. PMID: 31175762

[10] Hryn V. Kostylenko Y., Korchan, N., \& Lavrenko, D. (2019). Structural form of the follicle-associated epithelium of Peyers' patches of the albino rats' small intestine. Georgian medical news, 9(294), 118-123. PMID: 31687962

[11] Kolesnik, O. O. (2006). Treatment of patients with stromal tumors of the colon (GIST). Oncology, 3(8), 272-277.

[12] Nawaz, M., Shah, N., Zanetti, B. R., Maugeri, M., Silvestre, R. N., Fatima, F., ... \& Valadi, H. (2018). Extracellular vesicles and matrix remodeling enzymes: the emerging roles in extracellular matrix remodeling, progression of diseases and tissue repair. Cells, 7(10), 167. doi: 10.3390/cells7100167

[13] Lutsyk, O. D., Chaykovskyy, Yu. B. [Ed.] (2018). Histology. Cytology. Embryology: a textbook. Vinnytsia: Nova knyha.

[14] Omar, N. F., Gomes, J. R., Neves, J. D. S., \& Novaes, P. D. (2018). Effects of loss of occlusal contact on the expression of matrix metalloproteinase-2, membrane type 1-MMP, tissue inhibitor of the $\mathrm{mmP}-2$, eruption rate, organization and resistance of collagen fibers of the rat incisor periodontal ligament. Journal of periodontal research, 53(1), 40-46. doi: 10.1111/jre.12484

[15] Phillips, T. M., Fadia, M., Lea-Henry, T. N., Smiles, J., Walters, G. D., \& Jiang, S. H. (2017). mmP2 and mmP9 associate with crescentic glomerulonephritis. Clinical kidney journal, 10(2), 215-220. doi: 10.1093/ckj/sfw111

[16] Pronina, O. M., Koptev, M. M., Bilash, S. M., \& Yeroshenko, G. A. (2018). Response of hemomicrocirculatory bed of internal organs on various external factors exposure based on the morphological research data. World of medicine and biology, 1(63), 153-157. doi: 10.26.724/2079-8334-2018-1-63-153-157

[17] Ryngach, N. O., \& Keretsman, A. O. (2015). Diseases of the digestive system: historical parallels changes in classification andepidemiological situation. Family medicine, 4, 137-141.

[18] Xu, H., Bin, N. R., \& Sugita, S. (2018). Diverse exocytic pathways for mast cell mediators. Biochemical Society Transactions, 46(2), 235-247. doi: 10.1042/BST20170450

СТРУКТУРНА ОРГАНІЗАЦІЯ КЛУБОВОЇ КИШКИ ЛАБОРАТОРНИХ ТВАРИН В НОРМІ ТА У ПОРІВНЯЛЬНО-ВИДОВОМУ АСПЕКТІ Сидоренко M.I.

В останні десятиріччя широкого розповсюдження набули захворювання травної системи, які потребують негайного, як 
терапевтичного, так і хірургічного лікування і тому постає закономірне завдання оптимізації існуючих технологій та пошуку нових способів корекції вищезгаданих нозологій. Доклінічні дослідження таких розробок проводять виключно на лабораторних тваринах і знання морфологічних особливостей їх будови для подальшого порівняння з морфологією аналогічних органів людини є актуальним завданням сучасної медико-біологічної науки. Метою роботи було вивчення структурної організації клубової кишки кролів у порівняльно-видовому аспекті та для отримання контрольних даних щодо ї морфологічних особливостей. В роботі використані адекватні методи досліджень відповідно до поставленої мети, а саме: гістологічний, гістохімічний, електронно-мікроскопічний, морфометричний і статистичний та були вивчені біоптати клубової кишки 10 кролів. Оцінили правильність розподілу ознак за кожним із отриманих варіаційних рядів, середні значення за кожною вивченою ознакою, стандартні помилки та стандартні відхилення. Достовірність різниці значень між незалежними мікрометричними величинами при нормальному розподілі ознак визначали за критерієм Ст'юдента. В роботі охарактеризовані основні структурні компоненти клубової кишки кролів і порівняні з аналогічними структурами клубової кишки людини. Визначено, що клубова кишка кролів, як і у людини складається з чотирьох оболонок: слизової, підслизової, м'язової і серозної. Слизова оболонка побудована з епітеліального пласту, який розташовується на базальній мембрані і м'язовій пластинці і містить у своєму складі клітинні елементи (екзокриноцити, ентероцити різних видів, елементи дифузної ендокринної системи, асоційованої зі слизовою оболонкою, інтраепітеліальні лімфоцити), кровоносні і лімфратичні судини та нервові закінчення. Підслизова оболонка складається з пухкої волокнистої сполучної тканини, котра у своєму складі містить колагенові $і$ ретикулярні волокна, елементи дифузної лімфоїдної тканини, кровоносні судини і нервові закінчення. М'язова і серозна оболонки побудовані аналогічно клубовій кишці людини. Таким чином, після проведеного дослідження визначено, що морфологічна організація клубової кишки кролів на світлооптичному та електронно-мікроскопічному рівнях має загальні закономірності будови аналогічні клубовій кищці людини.

Ключові слова: клубова кишка, оболонки клубової кишки, екзокриноцити, ендокриноцити, лімфоцити, артеріоли, капіляри, венули.

\section{СТРУКТУРНАЯ ОРГАНИЗАЦИЯ ПОДВЗДОШНОЙ КИШКИ ЛАБОРАТОРНЫХ ЖИВОТНЫХ В НОРМЕ И В СРАВНИТЕЛЬНО- ВИДОВОМ АСПЕКТЕ \\ Сидоренко М. И.}

В последние десятилетия широкое распространение получили заболевания пищеварительной системы, требующие немедленного, как терапевтического, так и хирургического лечения и поэтому возникает закономерная задача поиска новых и оптимизация существующих технологий и способов коррекции вышеуказанных нозологий. Доклинические исследования таких разработок проводятся исключительно на лабораторных животных и знания морфологических особенностей их строения для последующего сравнения с морфологией аналогичных органов человека является актуальной задачей современной медико-биологической науки. Целью работы было изучение структурной организации подвздошной кишки кроликов в сравнительно-видовом аспекте и для получения контрольных данных относительно её морфологических особенностей. В работе использованы адекватные методы исследований в соответствии с поставленной целью, а именно: гистологический, гистохимический, электронно-микроскопический, морфометрический и статистический и были изучены биоптаты подвздошной кишки 10 кроликов. Оценили правильность распределения признаков по каждому из полученных вариационных рядов, средние значения по каждому изученному признаку, стандартные ошибки и стандартные отклонения. Достоверность различий значений между независимыми микрометрическими величинами при нормальном распределении признаков определяли по критерию Стьюдента. В работе охарактеризованы основные структурные компоненты подвздошной кишки кроликов и сравнению с аналогичными структурами подвздошной кишки человека. Определено, что подвздошная кишка кроликов, как и у человека состоит из четырех оболочек: слизистой, подслизистой, мышечной и серозной. Слизистая оболочка построена из эпителиального пласта, который располагается на базальной мембране и мышечной пластинке и содержит в своем составе клеточные элементы (экзокриноциты, энтероциты различных видов, элементы диффузной эндокринной системы, ассоциированной со слизистой оболочкой, интраэпителиальные лимфоциты), кровеносные и лимфратические сосуды и нервные окончания. Подслизистая оболочка состоит из рыхлой волокнистой соединительной ткани, которая в своем составе содержит коллагеновые и ретикулярные волокна, элементы диффузной лимфоидной ткани, кровеносные сосуды и нервные окончания. Мышечная и серозная оболочки построены аналогично подвздошной кишке человека. Таким образом, после проведенного исследования установлено, что морфологическая организация подвздошной кишки кроликов на светооптическом и электронно-микроскопическом уровнях имеет общие закономерности строения аналогичные подвздошной кишке человека.

Ключевые слова: подвздошная кишка, оболочки подвздошной кишки, экзокриноциты, эндокриноциты, лимфоциты, артериолы, капилляры, венулы. 